\title{
The stability of word stress across Mixean languages
}

\author{
Carmen Jany*
}

LSA Annual Meeting, Minneapolis, January 2-5, 2014

1. Introduction. Word stress patterns have been widely discussed for individual languages and in typological work (Van der Hulst 2010), but there are very few comparative studies in word stress within language families and across dialects. This paper examines stress patterns in Mixean varieties and how they relate to the phonological distinctions among these varieties. The term 'variety' is applied here, as studies and descriptions of Mixean languages are limited, and in a number of cases it has yet to be determined whether a particular variety constitutes its own language or a dialect.

2. Languages and data. The Mixean territory is located in Oaxaca, Mexico, and it is composed of 290 communities (Torres Cisneros 1997). Each community speaks its own variety, many of which are mutually unintelligible. Some linguists divide the Oaxaca Mixean language family into three main branches: Lowland Mixe, Midland Mixe, and Highland Mixe (INEA 1994, 1997). Wichmann's (1995) classification further subdivides Highland Mixe into North Highland Mixe and South Highland Mixe. Published grammars, dictionaries, and phonological descriptions of Mixean varieties include: De la Grasserie 1898, Dieterman 2008, Hoogshagen and Hoogshagen 1997, Jany 2010, Romero-Méndez 2008, Ruiz de Bravo Ahuja 1980, Schoenhals and Schoenhals 1982, Van Haitsma \& Van Haitsma 1976. This paper studies these secondary data. In addition, primary data from Chuxnabán Mixe (Midland Mixe) based on personal field work are examined.

3. Mixean phonologies. All Mixean varieties phonemically distinguish short (V), long (VV), glottalized (V' and/or VV'), interrupted (V'V), and aspirated(Vh and/or VVh) vowels and, depending on the variety, up to nine phonemic vowel qualities.

(1) ${ }^{1}$ Chuxnabán Mixe syllable nuclei

$\begin{array}{llll}\text { CVC: } & \text { kox } & {[\mathrm{kos}]} & \text { 'knee' } \\ \text { CVVC: } & \text { xooky } & {\left[\mathrm{so}^{\mathrm{j}}\right]} & \text { 'nail' } \\ \text { CV'C: } & \text { jo'kn } & {\left[\mathrm{ho}^{2} \mathrm{kn}\right]} & \text { 'hook' } \\ \text { CV'VC: } & \text { pa'am } & {\left[\mathrm{pa}^{2} \mathrm{am}\right]} & \text { 'disease' } \\ \text { CVVhC: } & \text { paajk } & {[\mathrm{pa}: \mathrm{h} \mathrm{k}]} & \text { 'bone' }\end{array}$

Major grammatical features, such as the inverse system, noun incorporation, and the distinction between 'dependent' and 'independent' verb marking, among others, remain constant across varieties. Dialectal distinctions are mainly based on the vowel system, i.e. the number of phonemic vowels, the type of syllable nuclei in roots (näx vs. naa ${ }^{h} x$ vs. naax 'earth'), and the vowel alternations conditioned by a following palatal consonant (këp vs. kipy vs. kepy 'tree'). Moreover, Mixean languages vary in regards to the stem alternations in conjugational verb classes. Verb stems change their phonemic shape according to which 'dependency' is marked. Some dialectal distinctions are illustrated in the following example (from Wichmann 1995):

\footnotetext{
* Carmen Jany, California State University, San Bernardino (cjany@csusb.edu).

${ }^{1}$ A note on orthography: glottal stops are represented as $\langle$ '>, the glottal fricative is represented as $\langle\mathrm{j}\rangle$, /ts/ represents a single consonant and phoneme, and long vowels are represented as two consecutive vowels. For a detailed account on the orthography see Jany 2010 .
} 
(2) Verb stem changes in Mixean

$\begin{array}{llll} & \text { 'earth’ } & \text { 'tree' } & \text { Example of verb stem alternation } \\ \text { North Highland Mixe } & \text { maax } & \text { këp } & \mathrm{VV}^{2} \mathrm{CC}>\mathrm{VV}^{2} \mathrm{C} \\ \text { South Highland Mixe } & \text { naahx } & \text { kipy } & \mathrm{V}^{2} \mathrm{CC}>\mathrm{VVC} \\ \text { South Midland Mixe } & \text { näx } & \text { kepy } & \\ \text { North Midland Mixe } & \text { naax } & \text { kepy } & \mathrm{V}^{2} \mathrm{CC}>\mathrm{VVC} \\ \text { Lowland Mixe } & \text { naax } & \text { kepy } & \mathrm{VVCC}>\mathrm{VVC}\end{array}$

4. Mixean stress pattern and syllable weight. While the phonologies show considerable differences among Mixean varieties, the stress pattern is invariant, even though it has been claimed to rely on syllabe weight (Hoogshagen 1984, Lyon 1980, Schoenhals and Schoenhals 1965, Van Haitsma and Van Haitsma 1976, Wichmann 1995). Syllable weight depends on the phonological structure of a word, in particular on syllable rimes (Gordon 2006). Following the dialectal variations outlined above, shifts in the stress pattern would be expected. However, this paper argues that syllable weight only plays a minor role in stress assignment, which depends largely on the morphology. Since the morphological structure remains invariant across Mixean varieties, the stress system remains intact. The Chuxnabán Mixe examples illustrate the stress pattern.

(3) Chuxnabán Mixe stress pattern
(a) 'ipxmëkoxk
'twenty-five'
(b) ja'anchukts
'ant'
(c) 'a'ktsa'a
'dragonfly'
(d) 'iixpachypy
'to get to know'
(e) 'uujts'atsëm
'wild boar'
(f) puuxtuk
'to cut with machete'
(g) kumyo'o
'bumblebee'
'aunt'
(h) tsëkuuj
'boss'
(j) 'uunyääpy
'to be seated down'
CVCC.CV.CVCC ${ }^{2}$
CV'VC.CVCC
CV'C.CV'V
CVVC.CVCC
CVVhC.CV.CVC
CVVC.CVC
CVC.CV'V
CV.CVVh
CVVC.CVVC
(k) wiimpiijtp
'to return'
CVV.CVVC
(l) kä'pënë
'scorpion scissors'
CVVC.CVVhCC
(m) 'ä'pinyë
'thorn'
(n) ne'pinyë
'blood'
(o) puujtpë
'grasshopper'
CVC.CV.CV
CVC.CV.CV
(p) tukwaanë
'to tell someone'
CVC.CV.CV
(q) joonëch
'birds'
CVVhC.CV
CVC.CVV.CV
CVV.CVC
(r) kaapx'oоyёp 'to clarify'
CVVCC.CVV.CVC
(s) wa'ako'oyëp 'to stop walking'
CV'V.CV'V.CVC
(t) mëja'aychëëjkëch 'ancestors'
(u) tëëjkochy 'inside the house'
CV.CV'VC.CVVh.CVC
CVVh. CVC $^{3}$

In Mixean, syllable weight determines stress assignment only in very few cases, namely in some polysyllabic roots. Generally, stress falls on the rightmost syllable of the root. Rarely, this syllable is $\mathrm{CV}$, the only light syllable type, in which case the penultimate or preceding syllable

\footnotetext{
${ }^{2}$ Roots are boldfaced; the stressed syllable is underlined.

3 -ochy is a locative suffix meaning 'inside' found on nouns and verbs and stemming from an ancient root.
} 
is stressed, as in (3d) - (31). Most suffixes are stressless, and prefixes never bear stress. Stressbearing suffixes result from the grammaticalization of ancient roots, as in (3u) tëëjkochy 'inside the house'. Stress assignment, then, is minimally sensitive to syllable weight relying primarily on morphological and diachronic factors.

However, Chuxnabán Mixe syllable weight is noticeable in two other areas: a) the minimal word can not be CV (see example 4) and b) when the suffixation of a CVC root leads to a resyllabification in order to avoid an onsetless syllable (CVC-VC $=>$ CV.CVC).

$$
\begin{aligned}
& \text { Chuxnabán Mixe smallest words } \\
& \begin{array}{lllll}
\text { CVV } & \text { CVC } & \text { CV'V } & \text { CVVh } & \text { CV'C }
\end{array} \\
& \text { kaa 'lion' kox 'knee' kë'ë 'hand' nëëj 'water' na't 'deaf' }
\end{aligned}
$$

No words with a CV' structure have been found. Therefore, I propose that the minimal word requirement is based on different weigth criteria than stress assignment. For the minimal word either CV or CV' count as light syllables, with all others being considered as heavy.

The second phonological process where syllable weight is observed involves cases in which adding a-CVC suffix to a root results in a re-syllabification to prevent having an onsetless syllable: $\underline{\mathrm{CVC}}-\mathrm{VC} \Rightarrow \mathrm{CV}$.CVC. Stress needs to be maintained on the root after suffixation, but this pattern leaves the otherwise heavy root syllable as a light syllable. To avoid stressing a light syllable, the coda consonant is geminated, thus functioning as the root coda and as the onset of the following syllable, as shown in (5). Onsetless syllables are not allowed in Mixean.

(5) Chuxnabán Mixe gemination to avoid stressing a light syllable
(a) jam
'there' $\quad->$ jam-ës
-> jammës
/jam.mës/
(b) mokkamp
'cornfield'
-> mokkamp-ën
-> mokkammën
(c) xon
'like' $\quad->$ xon-ës
-> xonnës
(d) champ
'now' ->champ-ën
-> chammën
(e) jap
'there' -> jap-ëk
-> jappëk
/mok.kam.mën/
/xon.nës/
/cham.mën/
/jap.pëk/

Gemination does not occur if the root still contains a heavy syllable after loosing its coda through re-syllabification, as in (6). For this process, CV' counts as a heavy syllable (see 6c), the same as for stress assignment.

(6) Chuxnabán Mixe: no gemination if root remains a heavy syllable
(a) kwaay
'horse' -> kwaay-ë
-> kwaayën
/kwaa.yën/
(b) ka'ap
'no, not' $\quad->$ ka'ap-ës
-> ka'apës
/ka'a.pës/
(c) 'i'k
'toy'
-> 'i'k-ës
-> 'i'k-ës
/’i'.kës /

To summarize, while syllable weight is observable in Mixean varieties, it minimally impacts the stress systems which are based on edge-oriented root stress. Stress patterns are further invariant across Mixean varieties in regards to Spanish loans. Generally, loans retain their original Spanish stress patterns (see 7a-b), but Spanish loans with are incorporated or affixed follow the Mixean stress pattern (see 7c-e).

Chuxnabán Mixe stress pattern involving Spanish loans

$\begin{array}{llll}\text { Mixe } & \text { Gloss } & \text { Spanish } & \text { Gloss } \\ \text { (a) semanë } & \text { 'week' } & \text { 'semana' 'week' } \\ \text { (b) toronjë } & \text { 'grapefruit' } & \text { 'toronja' 'grapefruit' } \\ \text { (c) cartonkochy } & \text { 'inside the box' } & \text { 'cartón' 'box' + -kochy 'inside' } \\ \text { (d) machetaajtëmë } & \text { 'our machete' } & \text { 'machete' 'machete' +-aajtëme 'our' }\end{array}$


(e) lämyëtëëjk 'sheet metal house' 'lámina' 'sheet metal' + tëëjk 'house'

5. Conclusions. Word stress does not vary in Mixean: it always falls on the rightmost heavy syllable $(\neq \mathrm{CV})$ of the root. In most cases, roots represent the only heavy syllable(s) in a word. As a result, syllable weight only plays a minimal role in stress assignment. Rather, the stress system rests upon edge-orientation and morphological conditioning. If the stress system relied to a greater extent on the phonological structure of words, some deviation would be expected, given that dialectal variations are primarily phonologically based. Interestingly, each system adopted the same stress rules for Spanish loans. Overall, this paper demonstrates how weight-sensitive stress patterns can remain stable across related languages even in light of major phonological differences. Furthermore, this work adds new data and analyses of lesser studied languages.

\section{References}

Crawford, John Chapman. 1963. Totontepec Mixe Phonotagmemics. Summer Institute of Linguistics, No. 8. University of Oklahoma.

De La Grasserie, Raoul. 1898 (reprint 1968). Langue Zoque et Langue Mixe: Grammaire, Dictionnaire. Biliothèque Linguistique Américaine, Tome XXII. Paris. Reprint: Kraus. Nendeln, Liechtenstein.

Dieterman, Julia. 2008. Secondary palatalization in Isthmus Mixe: a phonetic and phonological account. Summer Institute of Linguistics, Dallas, Texas.

Gordon, Matthew. 2006. Syllable Weight: Phonetics, Phonology, Typology. Routledge.

Hoogshagen, Searle 1984 Coatlán Mixe. In: Edmonson, Munro (ed.). Supplement to the Handbook of Middle American Indians. Volume 2. Austin: University of Texas Press, 3-19.

Hoogshagen Noordsy, Searle and Hilda Halloran Hoogshagen. 1997. Diccionario Mixe de Coatlán Oaxaca. $2^{\text {nd }}$ edition ( $1^{\text {st }}$ edition 1993). Mexico: Summer Institute of Linguistics.

INEA (Instituto Nacional para la Educación del los Adultos). 1994. Ayuk Ja'jy Y’ayuujk. Libro del Adulto, Población Mixe (Parte Baja), Oaxaca. http://cdi.gob.mx/index.php?id_seccion=519. (July 1, 2010)

INEA (Instituto Nacional para la Educación del los Adultos). 1997. Ayuk Ja’̄jy Y’ayuujk. Libro del Adulto, Población Mixe (Parte Alta), Oaxaca. (July 1, 2010)

Jany, Carmen. 2011. The phonetics and phonology of Chuxnabán Mixe. Linguistic Discovery. Dartmouth College Library http://cdi.gob.mx/index.php?id seccion=519. (July 1, 2010)

Jany, Carmen. 2010. Orthography design for Chuxnabán Mixe. Language Documentation \& Conservation 4. 231253.

Lyon, Shirley. 1967. Tlahuitoltepec Mixe Clause Structure. International Journal of American Linguistics 33:1. 2545.

Romero-Méndez, Rodrigo. 2008. A Reference Grammar of Ayutla Mixe (Tukyo'm Ayuujk). Dissertation. University of Buffalo: New York.

Ruiz de Bravo Ahuja, Gloria. 1980. Mixe Tlahuitoltepec. Oaxaca: Archivo de Lenguas Indígenas de México. (Data by Don D. Lyon)

Schoenhals, Alvin and Louise C. Schoenhals. 1982. Vocabulario Mixe de Totontepec. $2^{\text {nd }}$ edition $\left(1^{\text {st }}\right.$ edition 1965$)$. Hidalgo, Mexico: Summer Institute of Linguistics.

Torres Cisneros, Gustavo. 1997. Mixes. Comisión Nacional para el Desarrollo de los Pueblos Indígenas. http://www.cdi.gob.mx. (July 1, 2010)

Van der Hulst, Harry, Rob Goedemans, and Ellen van Zanten (eds). 2010. A survey of word accentual patterns in the languages of the world. Mouton: Berlin.

Van Haitsma, Julia Dieterman and Willard Van Haitsma. 1976. A Hierarchical Sketch of Mixe as spoken in San José El Paraíso. No. 44. Mexico: Summer Institute of Linguistics.

Wichmann, Søren. 1995. The Relationship among Mixe-Zoquean Languages of Mexico. University of Utah Press, Salt Lake City. 